\title{
The Impact of Moroccan Banks on Economic Growth in African Countries: Analyzing the Synchronization between the Financial and Business Cycles in WAEMU
}

\author{
El Bekri Hafsa
}

Center for Doctoral Studies in Economics and Management, Sidi Mohamed Ben Abdellah University, Morocco

Copyright $\mathrm{O} 2018$ by authors, all rights reserved. Authors agree that this article remains permanently open access under the terms of the Creative Commons Attribution License 4.0 International License

\begin{abstract}
The strategic choice of Moroccan banks to conquer the African market has accelerated since the mid-2000s. According to the Banking Commission of the West African Economic and Monetary Union (WAEMU), Moroccan banks concentrate $29.6 \%$ of the market share in the WAEMU region in 2015 , and more than $30 \%$ of the share of global net income in the region. The article is devoted to the research of the role of Moroccan banks in the economic development in African countries. Can Moroccan banks affect real economic activity and act as catalysts for financial and economic development in African countries? To answer this question, we examine the co-movements between loans granted by Moroccan banks in African countries and real activity in those countries. Therefore, we use the synchronization index proposed by Hading and Pagan (2002). The cycles were obtained with a Hodrick-Prescott (HP) filter. The concordance index values, cross-correlation values were used to identify the characteristics of the relationships between the cyclical components. The study covers the period 2006-2015 and focuses on three Moroccan banking groups (Attijariwafabank, BMCE Bank of Africa and Banque Centrale Populaire BCP) set up in seven countries: Benin, Burkina Faso, Côte d'Ivoire, Mali, Senegal, Togo and Niger. The empirical results revealed that the financial (credits granted by Moroccan banks) and business (real activity) cycles are highly synchronized in WAEMU. The study concluded that the bank credits have a positive impact on real activity in WAEMU countries within the period examined.
\end{abstract}

Keywords South-South Financial Flows, Moroccan Banks, African Countries, Concordance, Business Cycle, Financial Cycle

\section{Introduction}

The South-South relations are numerous, have great potential and could forge a new global order; they follow various modalities and involve a wide range of actors. There are many aspects of the changing landscape of economic relations amongst developing countries which appear as a very attractive way of promoting development in the South.

Foreign Direct Investment and financial flows represent significant economic development vectors for developing countries, particularly African economies which are lagging behind from the development point of view and are the fastest growing in the world.

The purpose of this paper is to explain how the spatial expansion of financial flows in South-South direction (from emerging economies to least developed ones) could contribute to the development of least developed countries.

To answer this question we describe financial aspect of South-South relations and we present empirical study on the effect of Moroccan banks' expansion in Africa particularly in the countries of the West African Economic and Monetary Union (WAEMU). Therefore we study the co-movements between loans granted by Moroccan banks and real activity in African countries.

While the ratio of investment to the gross domestic product (GDP) is used for business cycles, financial cycles are based on the ratio of Moroccan bank lending to GDP. In this paper, the Hodrick-Prescott filter (hereafter HP filter) is used to obtain the cyclical components of the variables. We calculate the concordance index as an indicator of the accordance and we determine the correlation analysis between cyclical components.

The paper is organized as follows. Section 2 reviews the related literature. Section 3 introduces the details of the empirical methodology. Section 4 provides the data and empirical results and Section 5 concludes the paper.

\section{Moroccan Bank's Expansion in Africa}

Three Moroccan Banks are present in Africa: ATTIJARIWAFABANK, Banque Centrale Populaire and 


\section{BMCE BANK OF AFRICA.}

In order to Study their impact on African economies, we developed a location map of the three Banks. The locations of the various subsidiaries have been established from their official websites and annual reports.

The internationalization of Moroccan banks on the African continent is justified by:

- The saturation of the national market: From the mid-2000s, the Moroccan banking sector could no longer grow faster than the economy and banking groups were in a competitive game that prevented them from gaining market share through acquisitions. The banks were faced with two choices; either to monitor the growth of the economy (5 to $6 \%$ ) and in this case, a problem of over-capitalization will occur, or to develop their business in markets that have high growth potential.

- The potential of the African markets: The low bancarization rates in most sub-Saharan countries.

- The expansion also responds to the need of banks to follow and support their clients, especially the industrial groups already present in Africa (OCP, MANAGEM, telephone operators...)

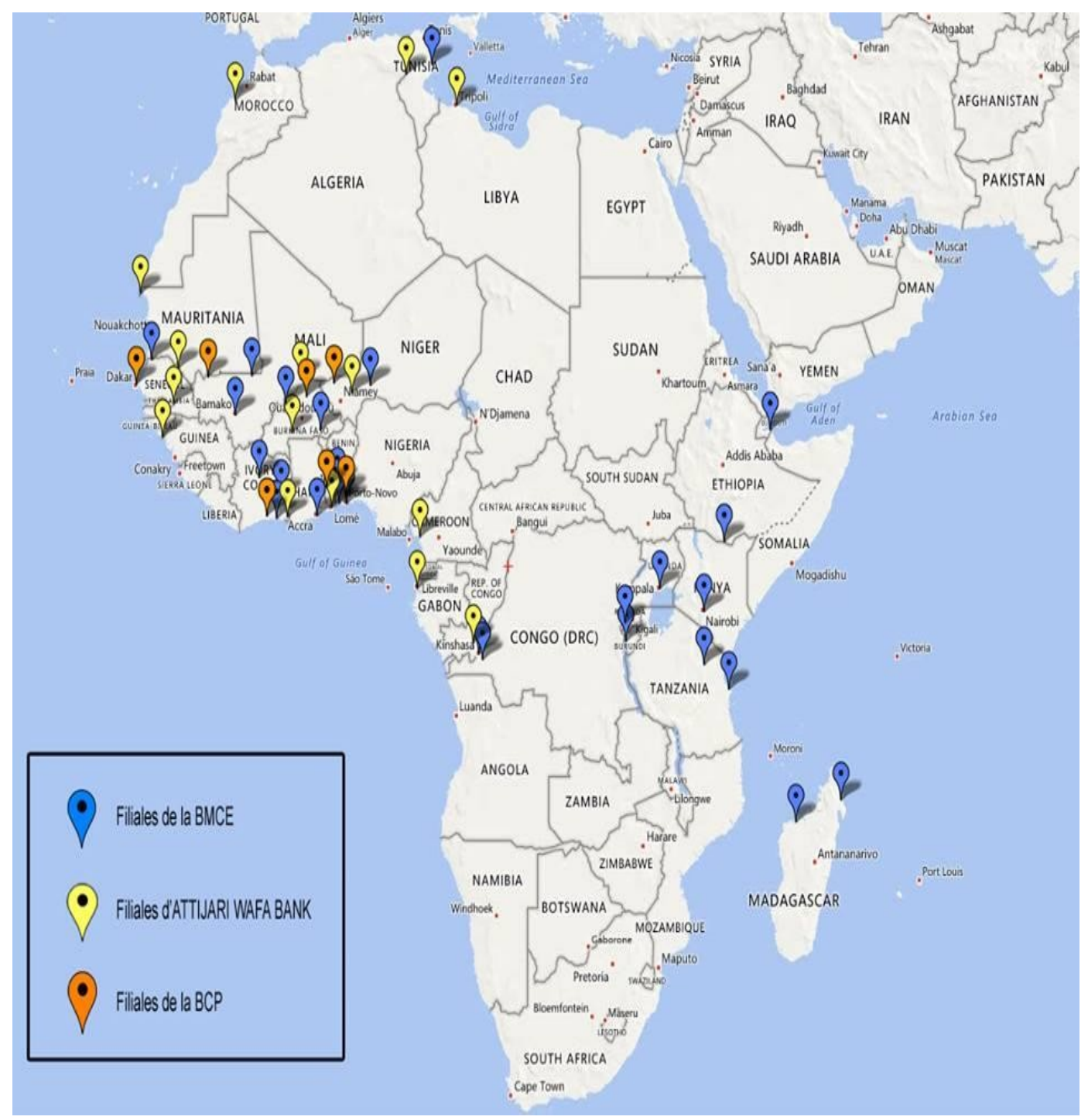

Source: Developed by the Author

Figure 1. Location map of the main Moroccan banks on the African market 


\section{Literature Review: Synchronization between Financial and Business Cycles}

The economic literature on the role of financial systems has undergone a revival since the second half of the twentieth century, and it revives the debate on the role of this financial system, particularly banks, in financing development. Several studies have highlighted the role of financial factors in amplifying cyclical fluctuations in economic activity.

The historical importance given to credits in the analysis of cycles can be explained by the large share of demand financed by credit in the economy.

The main objective of this study is to analyze the synchronization between financial and business cycles; it is first necessary to define the main features of financial and business cycles.

Several studies have identified the degree of synchronization between business and financial cycles. (Egert \& Sutherland, 2012 [1]) investigated the main characteristics of financial and business cycles and measured the degree of synchronization between these cycles in OECD countries. The authors explain that the financial mechanism works through the bank lending channel and balance sheet channel. Bank credit cycles can move in the same direction as the cycles in the real economy. Hence, this pro-cyclical feature of the banking sector may impact positively the real cycle.

(Borio, 2014 [2]) and (Drehmann, Borio and Tsatsaronis, [3] (2012) ) identify the core empirical features of financial cycles for better modeling strategies. Their main findings imply that banks and capital markets, as the main pillars of a financial system, can possibly influence real economic activity.

Although numerous papers have been written on the relationship between financial and business cycles, Credits increase significantly during business cycle expansions and decline during recessions. These changes in credits are sometimes more proportional to changes in economic activity, which means that increased bank credit can accentuate business cycles. However, specificities can be observed depending on the structure and development of the country's financial markets. In developing countries, financial markets are poorly developed and variable rate banking products are non-existent, making the banking sector a major player in the financial system. The bank credit channel is often the most important.

The study of the link between the credits and the economic activity in these countries would better refine the analysis of the impact of the Moroccan banks on the economic development of the West African countries (WAEMU).

(N'GUESSAN, 2010 [4]) studied the evolution of business and credits in the West African Economic and Monetary Union and concluded that credits and Business cycles are highly correlated in the Union. Banks have a pro-cyclical behavior with real activity. Therefore, it appeared important to study the concordance between the evolution of loans granted by Moroccan banks and the increase of investments in WAEMU countries over the period 2006-2015.

\section{Methodology}

\subsection{Measurement of Business and Financial Cycles}

The main method of measuring any cycle is the elimination of trends from the time series. The cyclical component of any time series can be achieved by subtracting the trend from the variable. Thus, this process allows for keeping only the fluctuations around the trend. The most popular filtering methods used to obtain the cyclical components of any time series are the HP filter, the Baxter-King band-pass filter and the Christiano-Fitzgerald band-pass filter. In this study, we used the HP filter to obtain the cyclical components of the corresponding variables. The choice of this filter is justified by the easy usage and comparability of the results between similar studies.

The HP filter removes a trend $\left(\tau_{t}\right)$ from the time series $y_{t}$. Where $y_{t}=\tau_{t}+c_{t} . c_{t}$ represents the deviations from the trend, which is the cyclical component of the $y_{t}$.

In this framework, Trends are extracted from the Hodrick Prescott filter with a parameter $\lambda=100$ (for annual data). The trend part of the time series can be determined by solving the following minimization problem:

$$
\frac{\operatorname{Min}}{\left\{\tau_{t}\right\}_{t=-1}^{T}}\left\{\sum_{t=1}^{T} c_{t}^{2}+\lambda \sum_{t=1}^{T}\left[\left(\tau_{t}-\tau_{t-1}\right)-\left(\tau_{t-1}-\tau_{t-2}\right)\right]^{2}\right\}
$$

Where $y_{t}=\tau_{t}+c_{t} . \lambda$ is the smoothing parameter and penalizes the variability in the trend, relative to the cyclical component. In many empirical studies, $\lambda=100$ for annual data.

\subsection{Dating Cycles}

The methodology of identifying peaks and troughs:

The BB algorithm is the most popular method for performing this task; it was introduced by (Bry, G. and Boschan,C. [5] 1971). This algorithm requires a search for the maximum and minimum points over the investigated period for a monthly series. (Harding, D. a.nd Pagan, P. [6] 2002) adapted the $B B$ algorithm and developed the quarterly version of the $\mathrm{BB}$ algorithm called the $\mathrm{BBQ}$.

In this study, we use annual data. A simple selection rule based on the periodicity of the series is used to identify the turning points of the financial and business cycles. The cycle is characterized by a succession of expansion and recession phases, each of which has a minimum duration of one year (because of the annual data used). Formally, expansion phases are defined as the time periods between a through and a peak. In contrast, the recession phases correspond to the periods separating a peak from a trough. 


$$
\left\{\begin{array}{c}
\left(Y_{t}-Y_{t-2}\right)>0,\left(Y_{t}-Y_{t-1}\right)>0 \\
\left(Y_{t+2}-Y_{t}\right)<0,\left(Y_{t+1}-Y_{t}\right)<0
\end{array}\right. \text { and }
$$

To avoid the intrusion of outliers into the universe of turning points, only the higher absolute fluctuations at half of the standard deviation of the cyclical component are retained.

Peaks and troughs are defined as follows:

$$
\begin{gathered}
c_{t} \text { is a peak if } c_{t}>\frac{1}{2} \sigma_{c} \text { with } \\
c_{t}>c_{t+1} \text { and } c_{t}>c_{t-1}, t \in[2 ; T-1] \\
c_{t} \text { is a trough if } c_{t}<-\frac{1}{2} \sigma_{c}
\end{gathered}
$$

with $\boldsymbol{c}_{\boldsymbol{t}}<\boldsymbol{c}_{\boldsymbol{t}+\mathbf{1}}$ and $\boldsymbol{c}_{\boldsymbol{t}}<\boldsymbol{c}_{\boldsymbol{t}-\mathbf{1}}, \mathrm{t} \mathrm{t}[2 ; \boldsymbol{T}-\mathbf{1}]$

The period between a peak and a trough is identified as a contraction, whereas the period between a trough and a peak is an expansion.

\subsection{Concordance}

After identifying the peak and trough points, the contraction and expansion phases for our variables can easily be defined. In this study, the concordance index developed by (Harding, A. \& Pagan, P. [7] 2006) is used as a concordance indicator between the business and financial cycles. The concordance index points out the average number of periods in which two variables ( $\mathrm{x}$ and $\mathrm{y}$ ) concur at the same phase of the cycle. It is calculated as follows:

$$
I C_{x y}=\frac{1}{T} \sum_{t=1}^{T}\left[S_{x, t} \cdot S_{y, t}+\left(1-S_{x, t}\right) \cdot\left(1-S_{y, t}\right)\right]
$$

Where:

$$
S_{t}^{x}=\left\{\begin{array}{c}
1, \text { if } x \text { is in expnsion at time } t \\
0, \text { otherwise }
\end{array}\right\}
$$

And

$$
s_{t}^{y}=\left\{\begin{array}{c}
1, \text { if } x \text { is in expnsion at time t } \\
0, \text { otherwise }
\end{array}\right\}
$$

The concordance index value changes from 0 to 1 . If it is equal to 1 , the investigated variables are always in the same phase. A value of 0 indicates that the variables are always in opposite phases.

\section{Data and Empirical Results}

We analyze the impact of Moroccan banks on African countries by answering the following question: How synchronized are financial and business cycles in WAEMU countries?

We construct an extensive data set using yearly series of financial and business variables for 7 countries covering the period 2006-2015. Our sample includes 3 Moroccan banks (Attijariwafabank, Banque Centrale Populaire, BMCE Bank of Africa) and 7 African countries.

\subsection{Source of Data}

We collect data of GDP growth rate and investment ratio from the World Bank database, the growth rate of credits granted by Moroccan banks in African countries from the Central bank of West African States BCEAO statistical database and the annual reports of the BCEAO [8-17].

\subsection{Empirical Results}

The basic data (The investment share in Gross domestic product (GDP) and the ratio of Moroccan bank lending to GDP in the West African countries) are given in the tables below.

The first step of the empirical analysis is to obtain the cyclical components of the investigated variables. After applying the HP filter on Eviews software, the cycles are obtained from Tables 1-2.

Tables 3 and 4 indicate the turning points for the expansion and recession periods (peaks are highlighted in green and troughs in red).

In the second step of the analysis, the concordance index value of the cycles is calculated according to the aforementioned procedure. The concordance index is presented in Table 5.

These results indicate that the investment cycle and credit volume cycles are highly synchronized in the countries of WAEMU. The other values also indicate that the synchronization degree between the financial and business cycles is high. Therefore, it can be concluded that business and financial cycles are in the same phase.

Table1. Investment Share in GDP in West African countries

\begin{tabular}{|l|c|c|c|c|c|c|c|c|}
\hline & Bénin & Burkina & Côte d'ivoire & Mali & Niger & Sénégal & Togo & WAEMU \\
\hline 2006 & 18.95 & 20.60 & 10.59 & 21.192 & 23.58 & 24.702 & 16.77 & 20.5 \\
\hline 2007 & 24.08 & 21.79 & 12.67 & 23.874 & 22.89 & 29.251 & 14.64 & 21.5 \\
\hline 2008 & 20.37 & 25.35 & 12.06 & 24.236 & 32.09 & 31.219 & 17.32 & 21.4 \\
\hline 2009 & 21.90 & 24.87 & 8.69 & 22.020 & 34.73 & 22.0607 & 17.98 & 23 \\
\hline 2010 & 23.13 & 26.9 & 13.43 & 24.0257 & 39.95 & 22.0407 & 18.93 & 22.1 \\
\hline 2011 & 24.13 & 27.9 & 4.70 & 19.7234 & 38.39 & 25.504 & 18.25 & 22.9 \\
\hline 2012 & 22.55 & 32.45 & 15.11 & 17.1830 & 36.17 & 29.098 & 24.19 & 21.5 \\
\hline 2013 & 27.81 & 32.42 & 20.71 & 18.4007 & 36.15 & 27.5424 & 24.56 & 23.7 \\
\hline 2014 & 28.57 & 31.23 & 18.96 & 18.1147 & 37.80 & 24.8034 & 23.14 & 22.7 \\
\hline 2015 & 25.97 & 31.78 & 20.78 & 17.890 & 38.82 & 23.7230 & 20.73 & 24.7 \\
\hline
\end{tabular}

Source: Author's calculation from World Bank Database 
Table 2. Credits granted by Moroccan banks in African countries (\%GDP)

\begin{tabular}{|l|l|l|l|l|l|l|l|l|l|}
\hline \multicolumn{7}{|c|}{ Credits granted by Moroccan banks in West African countries (\%GDP) } \\
\hline 2006 & 3.89 & 1.57 & 0.57 & 1.12 & 0.91 & 0.48 & 0 & 1.342 \\
\hline 2007 & 5.01 & 1.63 & 0.87 & 1.5 & 1.52 & 1.939 & 0 & 2.180 \\
\hline 2008 & 5.896 & 2.02 & 1.05 & 1.64 & 2.07 & 5.87 & 0 & 3.105 \\
\hline 2009 & 6.555 & 2.13 & 2.07 & 3.83 & 2.41 & 5.946 & 0 & 4.064 \\
\hline 2010 & 7.011 & 2.47 & 2.52 & 4.13 & 2.72 & 6.274 & 0 & 4.513 \\
\hline 2011 & 7.017 & 2.77 & 2.67 & 4.85 & 3.03 & 6.749 & 0 & 4.693 \\
\hline 2012 & 6.732 & 5.28 & 3.66 & 5.46 & 4.5 & 7.396 & 5.79 & 5.079 \\
\hline 2013 & 7.263 & 7.265 & 4.617 & 6.804 & 4.786 & 8.372 & 6.24 & 6.232 \\
\hline 2014 & 7.724 & 8.909 & 5.189 & 7.489 & 4.855 & 9.180 & 5.94 & 7.193 \\
\hline 2015 & 7.951 & 8.770 & 6.563 & 7.461 & 5.269 & 9.501 & 6.65 & 7.447 \\
\hline
\end{tabular}

Source: Author's Calculation based on Central Bank of West African States BCEAO

Table 3. Credits granted By Moroccan Banks Cycle

\begin{tabular}{|c|c|c|c|c|c|c|c|c|}
\hline \multicolumn{7}{|c|}{ Credit Cycle } \\
\hline & Bénin & Burkina Faso & Cote d'ivoire & Mali & Niger & Sénégal & Togo & WAEMU \\
\hline $\mathbf{2 0 0 6}$ & -0.799 & 1.193 & 0,43 & 0.2626 & -0.04018 & -1.4345 & 1.39709 & -0.2532123 \\
\hline $\mathbf{2 0 0 7}$ & -0.124 & 0.472 & 0,127 & -0.151 & 0.06859 & -1.0004 & 0.631535 & -0.0901107 \\
\hline $\mathbf{2 0 0 8}$ & 0.324 & 0.068 & $-0,299$ & -0.808 & 0.1177 & 1.91997 & -0.14799 & 0.1625229 \\
\hline $\mathbf{2 0 0 9}$ & 0.564 & -0.643 & 0,1038 & 0.5808 & -0.0429 & 1.0240 & -0.96178 & 0.45512 \\
\hline $\mathbf{2 0 1 0}$ & 0.624 & -1.171 & -0.0755 & 0.0827 & -0.2349 & 0.4240 & -1.82863 & 0.24549 \\
\hline $\mathbf{2 0 1 1}$ & 0.257 & -1.796 & $-0,5711$ & 0.0096 & -0.4294 & 0.0097 & -2.7577 & -0.22810 \\
\hline $\mathbf{2 0 1 2}$ & -0.382 & -0.267 & $-0,2456$ & -0.1686 & 0.5351 & -0.2030 & 2.0500 & -0.49586 \\
\hline $\mathbf{2 0 1 3}$ & -0.197 & 0.699 & 0.0306 & 0.3920 & 0.3201 & -0.0669 & 1.5012 & 0.00028 \\
\hline $\mathbf{2 0 1 4}$ & -0.077 & 1.309 & $-0,0889$ & 0.3006 & -0.1069 & -0.0862 & 0.2022 & 0.30338 \\
\hline $\mathbf{2 0 1 5}$ & -0.1897 & 0.135 & 0,5876 & -0.49869 & -0.18718 & -0.5866 & -0.0859 & -0.099512 \\
\hline standard deviation & 0.442 & 0.997 & 0,385 & 0.423 & 0.278 & 0.964 & 1.518 & 0.291 \\
\hline $1 / 2$ standard deviation & 0.221 & 0.4985 & 0.1925 & 0.2115 & 0.139 & 0.482 & 0.759 & 0.1455 \\
\hline
\end{tabular}

Table 4. Business Cycle in WAEMU Countries

\begin{tabular}{|c|c|c|c|c|c|c|c|c|}
\hline \multicolumn{9}{|c|}{ Business Cycle } \\
\hline & Bénin & Burkina Faso & Cote d'ivoire & Mali & Niger & Sénégal & Togo & WAEMU \\
\hline $\mathbf{2 0 0 6}$ & -1.1684 & $-0,5929$ & 1,427 & $-2,5357$ & $-2,51$ & $-2,228$ & 1,26 & $-0,4195$ \\
\hline $\mathbf{2 0 0 7}$ & 3.1618 & $-0,8766$ & 2,673 & 0,7439 & $-5,241$ & 2,5205 & $-1,795$ & 0,242 \\
\hline $\mathbf{2 0 0 8}$ & -1.3266 & 1,2194 & 1,2249 & 1,7296 & 1,923 & 4,7117 & $-0,0517$ & $-0,192$ \\
\hline $\mathbf{2 0 0 9}$ & -0.5884 & $-0,7022$ & $-3,0497$ & 0,1807 & 2,654 & $-4,204$ & $-0,33097$ & 1,079 \\
\hline $\mathbf{2 0 1 0}$ & -0.1622 & $-0,0626$ & 0,6795 & 2,896 & 6,1085 & $-4,013$ & $-0,329$ & $-0,1389$ \\
\hline $\mathbf{2 0 1 1}$ & 0.0169 & $-0,4134$ & $-9,1958$ & $-0,6529$ & 2,984 & $-0,3764$ & $-1,937$ & 0,345 \\
\hline $\mathbf{2 0 1 2}$ & -2.394 & 2,727 & $-0,0839257$ & $-2,4275$ & $-0,6355$ & 3,3841 & 3,079 & $-1,374$ \\
\hline $\mathbf{2 0 1 3}$ & 2.0138 & 1,417 & 4,10677 & $-0,455$ & $-1,963$ & 2,0233 & 2,5838 & 0,4945 \\
\hline $\mathbf{2 0 1 4}$ & 1.9362 & $-1,02307$ & 0,92 & 0,00326 & $-1,562$ & $-0,488$ & 0,3553 & $-0,844$ \\
\hline $\mathbf{2 0 1 5}$ & -1.489 & $-1,69307$ & 1,298 & 0,5177 & $-1,764$ & $-1,328$ & $-2,835$ & 0,8081 \\
\hline Standard deviation & 1,80269651 & 1,35942691 & 3,71798293 & 1,67292923 & 3,34226503 & 3,07289379 & 1,91780475 & 0,75068379 \\
\hline $\mathbf{1 / 2}$ standard deviation & 0,90134825 & 0,67971346 & 1,85899146 & 0,83646462 & 1,67113252 & 1,5364469 & 0,95890237 & 0,37534189 \\
\hline
\end{tabular}


The Impact of Moroccan Banks on Economic Growth in African Countries: Analyzing the Synchronization between the Financial and Business Cycles in WAEMU

Table 5. Credit Cycle Characteristics

\begin{tabular}{|c|c|c|c|c|}
\hline & Phase of expansion & Phase of contraction & $\begin{array}{l}\text { Average duration of } \\
\text { Cycle }\end{array}$ & volatility $^{1}$ \\
\hline Bénin & $2007-2010$ & 2010-2012 & $3.5^{2}$ & 0.41 \\
\hline Burkina Faso & 2011-2014 & 2006-2011 & 5 & 0.71 \\
\hline Cote d'ivoire & $2006-2009$ & $2009-2012$ & 4 & 0.44 \\
\hline Mali & $\begin{array}{c}2008-2009 ; \\
2012-2013\end{array}$ & $2009-2012$ & 2.3 & 0.46 \\
\hline Niger & 2006-2010 & $2010-2014$ & 5 & 0.33 \\
\hline Sénégal & $2007-2008$ & $2008-2015$ & 5 & 0.92 \\
\hline Togo & $2009-2012$ & $\begin{array}{c}2007-2009 \\
2012-2014\end{array}$ & 3.33 & 0.61 \\
\hline $\begin{array}{l}\text { WAEMU (Except } \\
\text { guinée Bissau) }\end{array}$ & 2012-2014 & $2009-2012$ & 3.5 & 0.29 \\
\hline
\end{tabular}

Table 6. Investment Cycle Characteristics

\begin{tabular}{|c|c|c|c|c|}
\hline & Phase of expansion & Phases of contraction & Average duration of cycle & Volatility \\
\hline Bénin & $\mathbf{2 0 1 2 - 2 0 1 3}$ & $\mathbf{2 0 0 7 - 2 0 1 2}$ & $\mathbf{4}$ & $\mathbf{1 . 8}$ \\
\hline Burkina Faso & $\mathbf{2 0 0 7 - 2 0 0 8 ; 2 0 0 9 - 2 0 1 2}$ & $\mathbf{2 0 0 8 - 2 0 0 9 ; 2 0 1 2 - 2 0 1 4}$ & $\mathbf{2 . 7 5}$ & $\mathbf{1 . 3 5}$ \\
\hline Cote d'ivoire & $\mathbf{2 0 1 1 - 2 0 1 3}$ & $\mathbf{2 0 0 7 - 2 0 1 1}$ & $\mathbf{4}$ & $\mathbf{3 . 7 1}$ \\
\hline Mali & $\mathbf{2 0 1 2 - 2 0 1 5}$ & $\mathbf{2 0 1 0 - 2 0 1 2}$ & $\mathbf{3 . 5}$ & $\mathbf{1 . 6 7}$ \\
\hline Niger & $\mathbf{2 0 0 7 - 2 0 1 0}$ & $\mathbf{2 0 1 0 - 2 0 1 3}$ & $\mathbf{4}$ & $\mathbf{3 . 3 4}$ \\
\hline Sénégal & $\mathbf{2 0 0 9 - 2 0 1 2}$ & $\mathbf{2 0 0 8 - 2 0 0 9}$ & $\mathbf{3}$ & $\mathbf{3 . 0 7}$ \\
\hline Togo & $\mathbf{2 0 1 1 - 2 0 1 2}$ & $\mathbf{2 0 1 2 - 2 0 1 5}$ & $\mathbf{3}$ & $\mathbf{1 . 9 1}$ \\
\hline WAEMU (Except guinée Bissau) & $\mathbf{2 0 1 2 - 2 0 1 3}$ & $\mathbf{2 0 0 9 - 2 0 1 2}$ & 3 & $\mathbf{0 . 7 5}$ \\
\hline
\end{tabular}

Table 7. The Concordance Index

\begin{tabular}{|c|c|c|c|c|c|c|c|c|}
\hline Countries & Bénin & Burkina Faso & Côte d'ivoire & Mali & Niger & Sénégal & Togo & WAEMU \\
\hline & 0.046 & -0.088 & 0.55 & -0.29 & -0.39 & 0.139 & 0.66 & 0.39 \\
\hline
\end{tabular}

The graphs below, isolating the trend cycle, give an overview of the cyclical profile of bank loans (granted by Moroccan banks) and investment in WAEMU.

Hodrick-Prescott Filter (lambda=100)

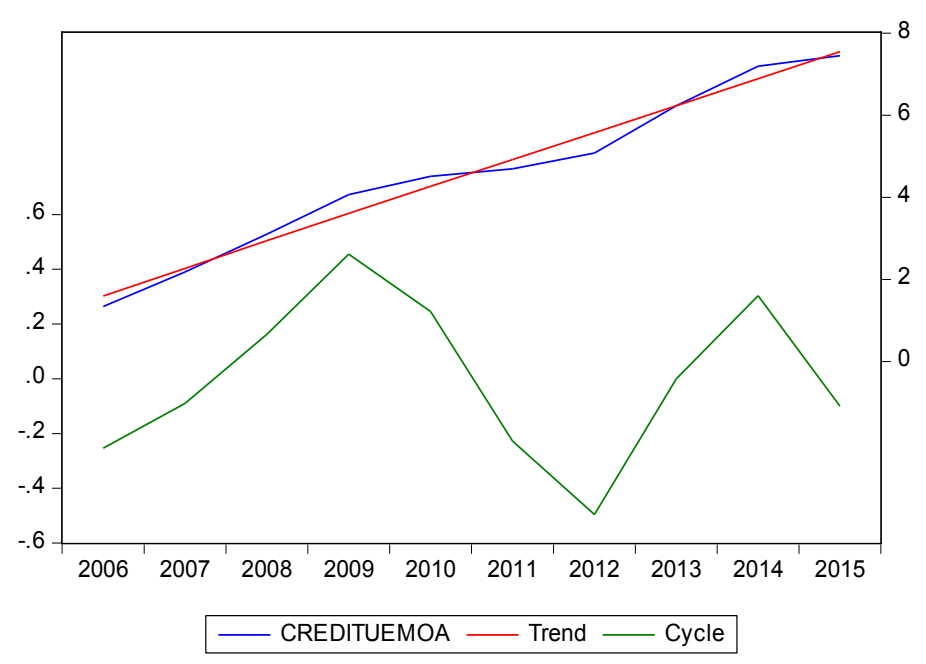

Figure2. Cyclical Profile of Credits granted by Moroccan Banks in WAEMU 


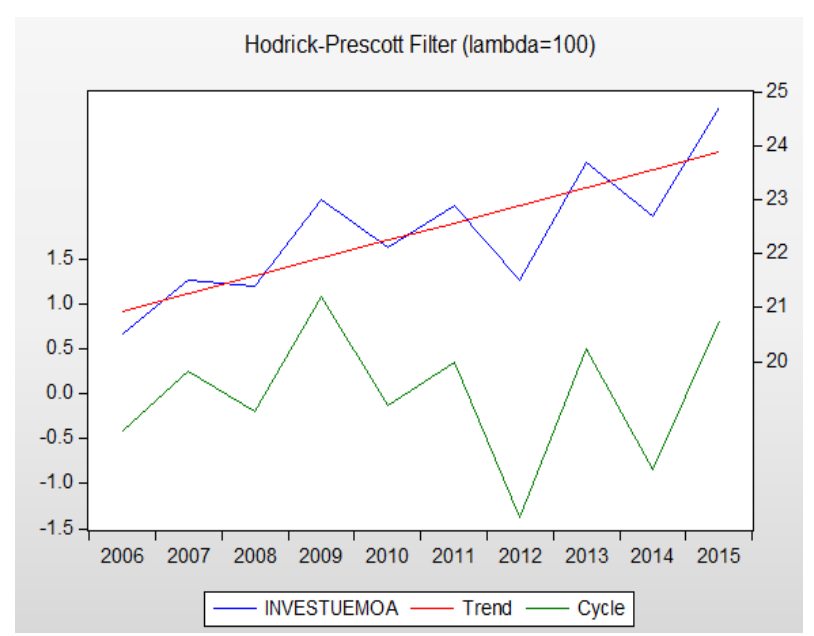

Figure 3. Cyclical Profile of Investment in WAEMU

The credit cycle has different characteristics within the countries of the Union. For the Union as a whole, the average duration of the cycle is 3.5 years. This duration is greater in Benin, Burkina Faso, Senegal, Niger and Côte d'Ivoire. Relatively shorter cycles are observed in Mali and Togo. Differences are also noted in the volatility of credit within cycles. This is relatively less important in Niger, Benin and Côte d'Ivoire than in other WAEMU countries.

The phases of credit expansion generally concern the periods 2009-2012. The credit contraction phases were observed over the 2007-2009 and 2012-2014 periods.

The investment cycle has similar characteristics as the credit cycle. By country, the average duration of the investment cycle is shorter in Burkina, Senegal and Togo compared to other countries in the zone. The phases of expansion of the activity in the Union extend over the periods 2009-2013, while those of contraction of the investment concern the period 2007-2009.

The results from the findings imply that the relationship between credit cycle (credits granted by Moroccan Banks) and the real business cycle was pro-cyclical in the WAEMU.

By country, the cyclical component of credit is positively related to the Business cycle in four countries of the Union. This result indicates that during the period under review (2006-2015), credit was pro-cyclical to investments in Benin, Senegal, Côte d'Ivoire, and Togo while it was contra-cyclical in the case of Burkina Faso, Mali and Niger.

\section{Conclusions}

The particularity of our study is to analyze the impact of South-South financial flows on least developed countries.

Our findings highlight three main conclusions. The credits offered by Moroccan banks have accompanied the economic activity in WAEMU. More specifically, during the phases of expansion of real activity, Moroccan banks proceed to a strong distribution of credits, while they reduce the volume of loans during a recession. Credits are pro-cyclical to economic activity. This co-movement of credit and activity shows that Moroccan banks have a positive impact on real activity in WAEMU countries. They finance investment in these countries and thereby contribute to their economic growth.

\section{Appendix}

\section{Benin}

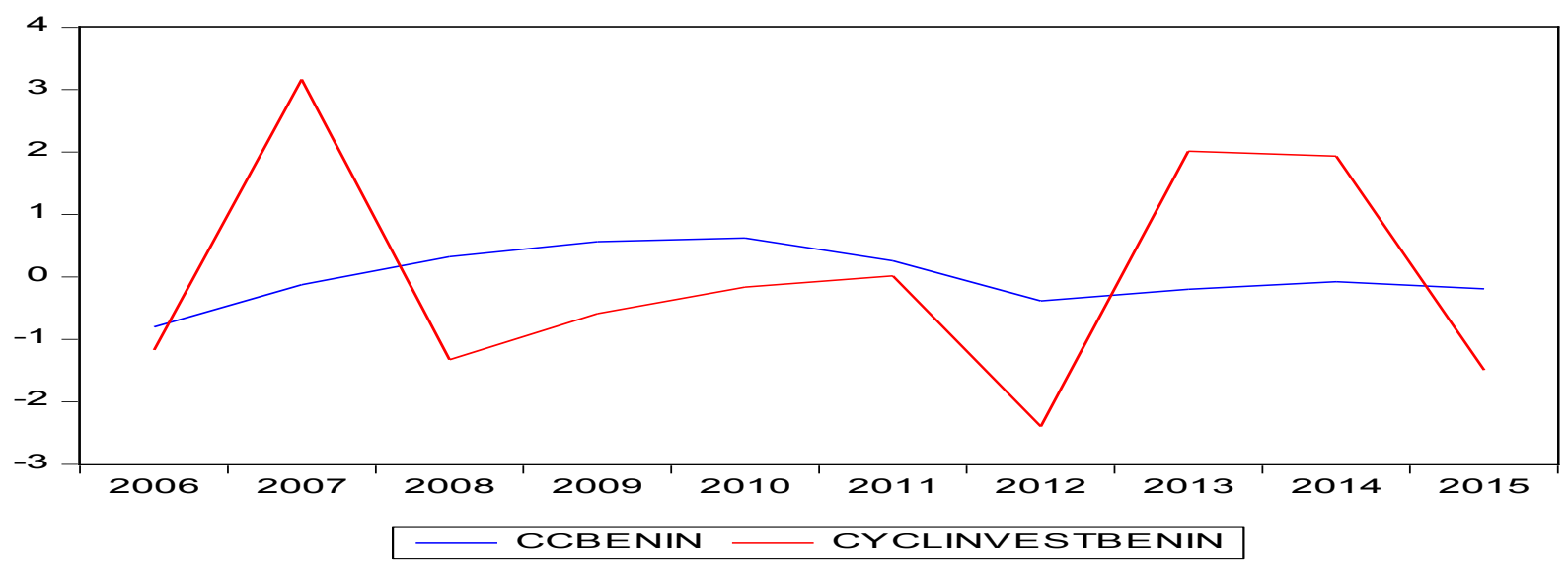

Figure 4. Business and Financial Cycles in Benin 
Table 8. Cross-Correlation Values in Benin

\begin{tabular}{|c|c|c|}
\hline & Credit Cycle BENIN & CYCLINVESTBENIN \\
\hline Credit Cycle BENIN & 1 & 0.04625391161236443 \\
\hline CYCLINVESTBENIN & 0.04625391161236443 & 1 \\
\hline
\end{tabular}

Source : Eviews software Calculation

\section{Burkina Faso}

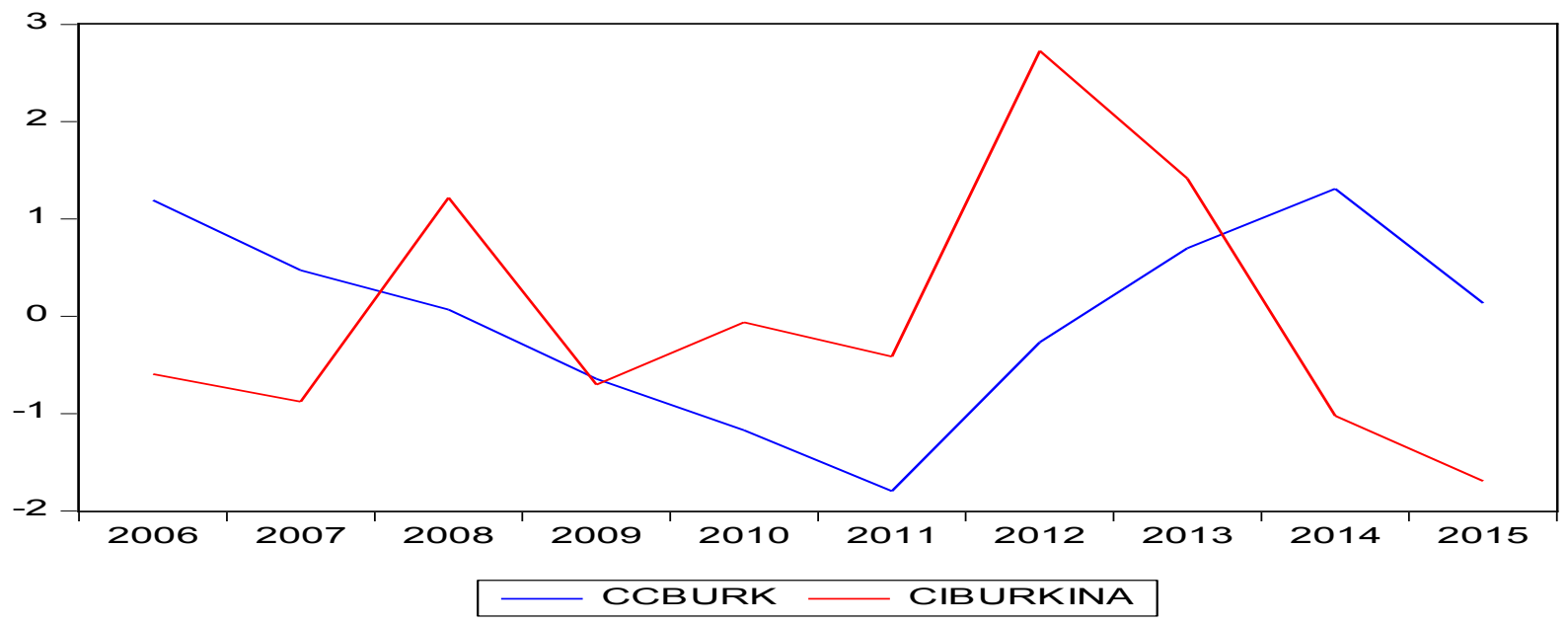

Figure 5. Business and Financial Cycles in Burkina Faso

Table 9. Cross-correlation values in Burkina Faso

\begin{tabular}{|c|c|c|}
\hline & Cycle Crédit BURKina & Cycle d' investment BURKINA \\
\hline Cycle crédit BURK & 1 & -0.08818499820691578 \\
\hline Cycle investment BURKINA & -0.08818499820691578 & 1 \\
\hline
\end{tabular}

Source : Eviews software Calculation

\section{Côte d'ivoire}

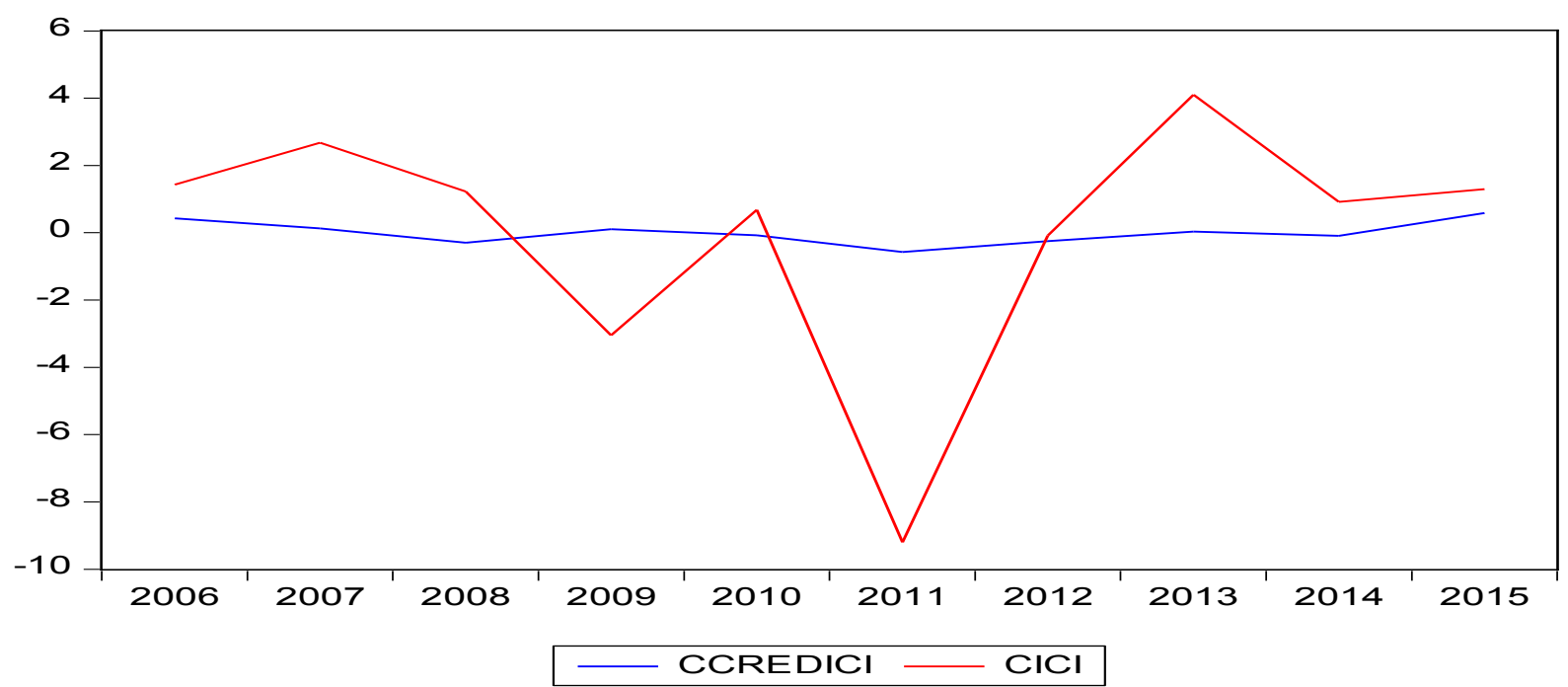

Figure 6. Business and Financial Cycles in Cote d'ivoire 
Table 10. Cross-correlation values in Côte d'ivoire

\begin{tabular}{|c|c|c|}
\hline & CCREDICI & CICI \\
\hline CCREDICI & 1 & 0.5517038185635752 \\
\hline CICI & 0.5517038185635752 & 1 \\
\hline
\end{tabular}

Source : Eviews software Calculation

Mali

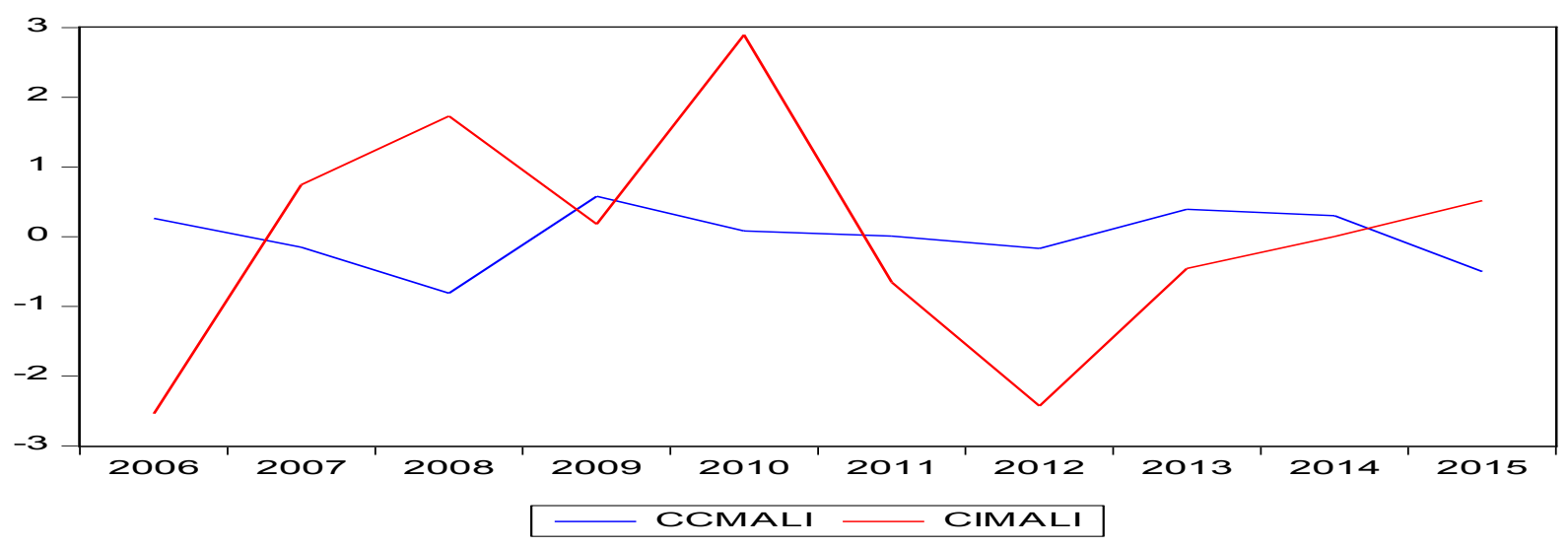

Figure 7. Business and Financial Cycles in Mali

Table 11. Cross-correlation values in Mali

\begin{tabular}{|c|c|c|}
\hline & CCMALI & CIMALI \\
\hline CCMALI & 1 & -0.2928546920535239 \\
\hline CIMALI & -0.2928546920535239 & 1 \\
\hline
\end{tabular}

Source : Eviews software Calculation

Niger

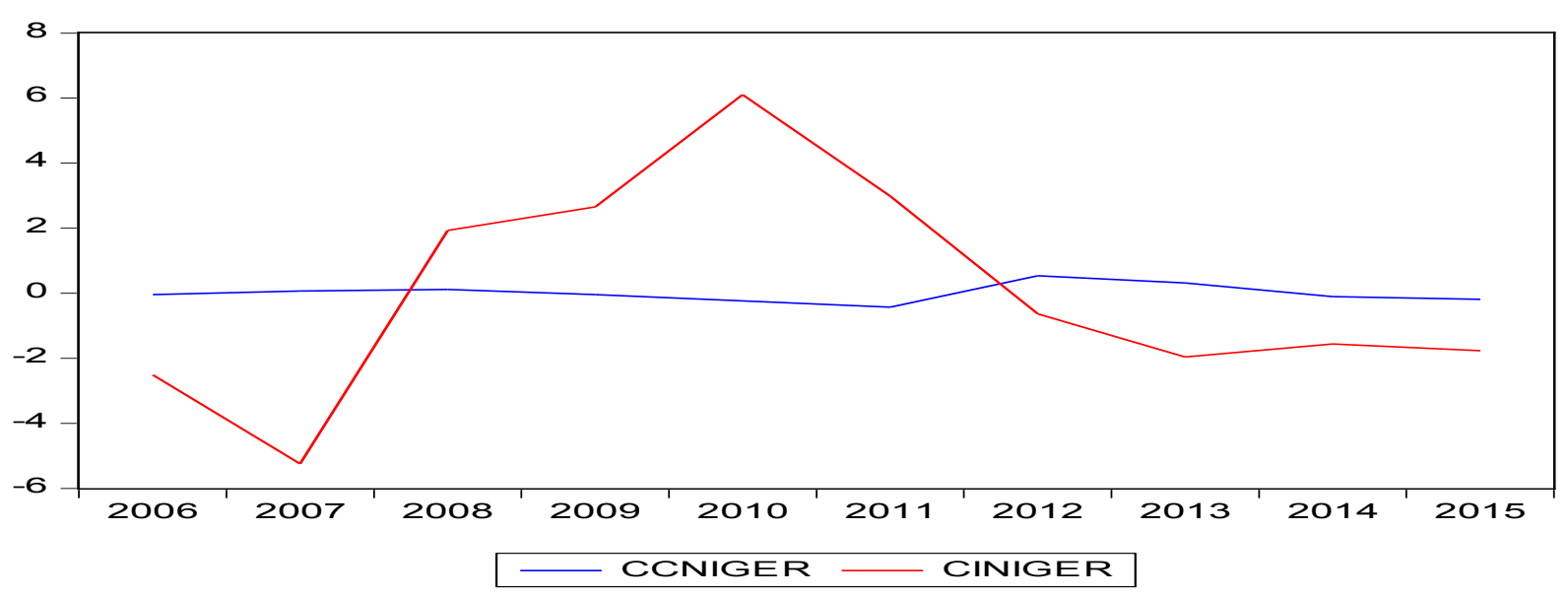

Figure 8. Business and Financial cycles in Niger

Table 12. Cross-correlation values in Niger

\begin{tabular}{|c|c|c|}
\hline & Credit Cycle NIGER & Investment Cycle NIGER \\
\hline Credit Cycle NIGER & 1 & -0.3982145964140514 \\
\hline Investment CycleNIGER & -0.3982145964140514 & 1 \\
\hline
\end{tabular}

Source : Eviews software Calculation 


\section{SENEGAL}

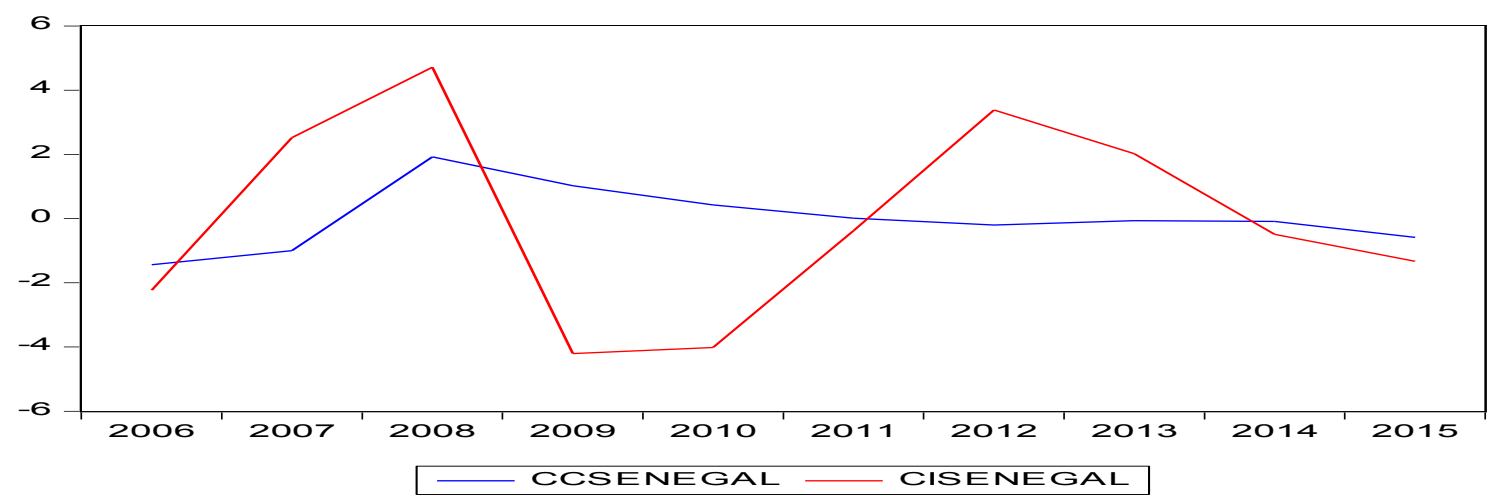

Figure 9. Business and Financial Cycles in Senegal

Table 13. Cross-correlation Values in Senegal

\begin{tabular}{|c|c|c|}
\hline & CCSENEGAL & CISENEGAL \\
\hline CCSENEGAL & 1 & 0.1390177142752638 \\
\hline CISENEGAL & 0.1390177142752638 & 1 \\
\hline
\end{tabular}

Source : Eviews softaware Calculation

\section{TOGO}

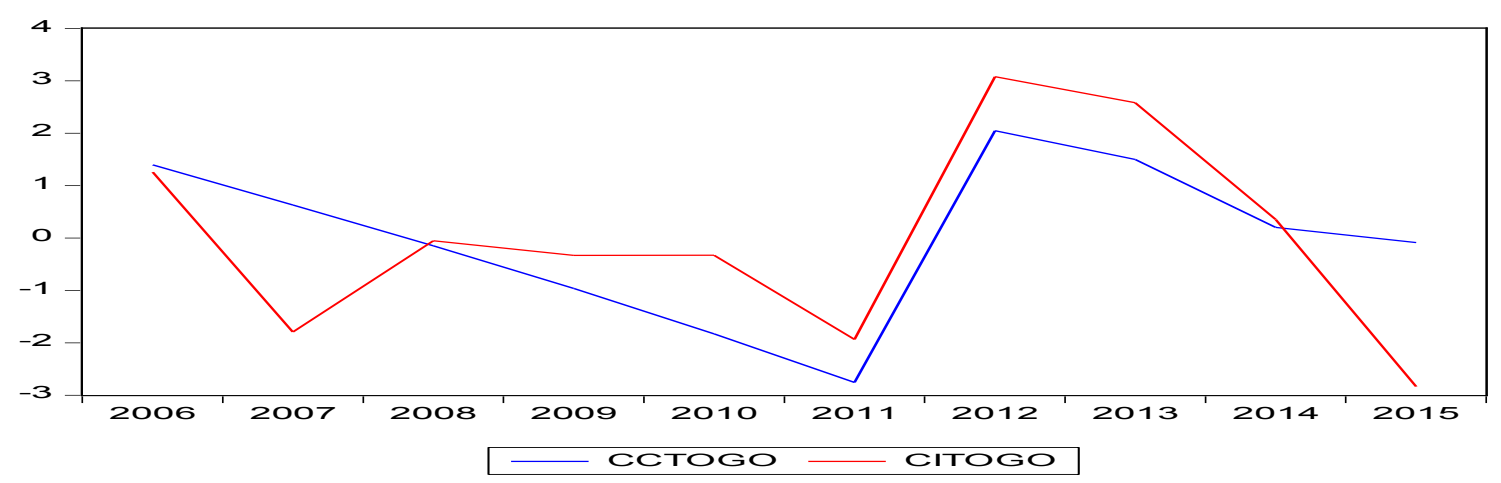

Figure 10. Business and Financial cycles in Togo

Table 14. Cross-correlation values in Togo

\begin{tabular}{|c|c|c|}
\hline & CCTOGO & CITOGO \\
\hline CCTOGO & 1 & 0.6640251403222969 \\
\hline CITOGO & 0.6640251403222969 & 1 \\
\hline
\end{tabular}

Source : Eviews softaware Calculation

\section{WAEMU}

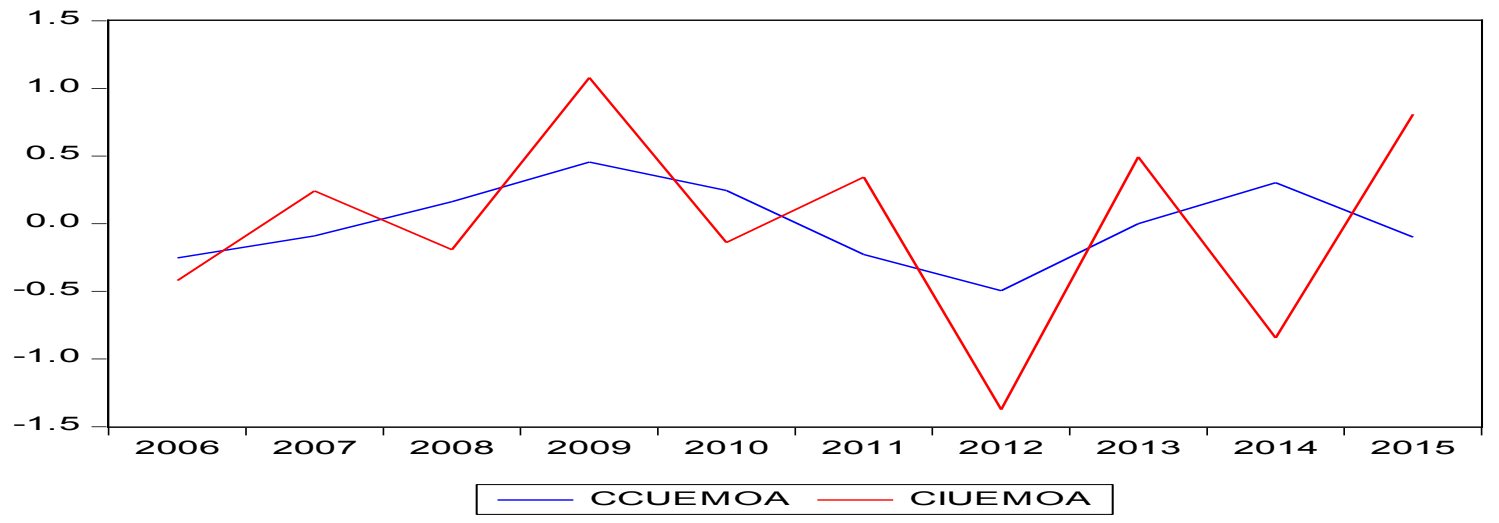

Figure 11. Business and financial cycles in WAEMU 
Table 15. Cross-correlation values in WAEMU

\begin{tabular}{|c|c|c|}
\hline & CC WAEMU & CI WAEMU \\
\hline CC WAEMU & 1 & 0.3938964587888737 \\
\hline CI WAEMU & 0.3938964587888737 & 1 \\
\hline
\end{tabular}

Source : Eviews software Calculation

\section{Acronyms}

BB algorithm: Bry and Boschan algorithm

BCEAO: Central bank of West African States

GDP: Gross Domestic Product

HP filter: Hodrick-Prescott filter

OECD countries: Organization for Economic Cooperation and Development member countries.

WAEMU: West African Economic and Monetary Union

\section{REFERENCES}

[1] Egert, B., \& Sutherland, D. (2012). The Nature of Financial and Real Business Cycles: The Great Moderation and Banking Sector Pro-Cyclicality. CESIFO WORKING PAPER NO. 3824 CATEGORY 6: FISCAL POLICY, MACROECONOMICS AND GROWTH

[2] Borio, C., 2014. "The financial cycles and macroeconomics: What have we learnt?" Journal of Banking \& Finance. 45:182-198.

http://dx.doi.org/10.1016/j.jbankfin.2013.07.031

[3] Drehmann, M., Borio, C., \& Tsatsaronis, K. (2012). Characterising the financial cycle: don't lose sight of the medium term. Bank for International Settlements Working Papers 380 June.

[4] N'guessan, B-A. (2010) Analyse comparée des évolutions du crédit et de l'activité économique dans l'UEMOA, BCEAO Département des études économiques et de la monnaie, direction de la recherche et de la statistique $n^{\circ} \mathrm{DER} / 10 / 01$

[5] Bry, G. and Boschan, C. (1971), Cyclical analysis of time series: selected procedures and computer programs, technical paper 20, New York: Columbia University Press for NBER.

[6] Harding, D. and Pagan, A. (2002). Dissecting the Cycle: A Methodological Investigation. Journal of Monetary Economics 49 (2), 365-381.
[7] Harding, D., \& Pagan, A. (2006). Synchronisation of Cycles. Journal of Econometrics, 59-79.

[8] RAPPORT ANNUEL DE LA COMMISSION BANCAIRE DE L'UEMOA 2006

[9] RAPPORT ANNUEL DE LA COMMISSION BANCAIRE DE L'UEMOA 2007

[10] RAPPORT ANNUEL DE LA COMMISSION BANCAIRE DE L'UEMOA 2008.

[11] RAPPORT ANNUEL DE LA COMMISSION BANCAIRE DE L'UEMOA 2009.

[12] RAPPORT ANNUEL DE LA COMMISSION BANCAIRE DE L'UEMOA 2010.

[13] RAPPORT ANNUEL DE LA COMMISSION BANCAIRE DE L'UEMOA 2011.

[14] RAPPORT ANNUEL DE LA COMMISSION BANCAIRE DE L'UEMOA 2012.

[15] RAPPORT ANNUEL DE LA COMMISSION BANCAIRE DE L'UEMOA 2013.

[16] RAPPORT ANNUEL DE LA COMMISSION BANCAIRE DE L'UEMOA 2014.

[17] RAPPORT ANNUEL DE LA COMMISSION BANCAIRE DE L'UEMOA 2015. 